\title{
Oxiniacic Acid
}

National Cancer Institute

\section{Source}

National Cancer Institute. Oxiniacic Acid. NCI Thesaurus. Code C66269.

A nicotinic acid derivative. 